\title{
Service Quality Sebagai Pengukuran Kepuasan Siswa dan Orang Tua/Wali Murid SMP Muhammadiyah 1 Gombong
}

\author{
Gempar Pribadi $^{1)}$ \\ 1) Magister Manajemen, Fakultas Ekonomi dan Bisnis, Universitas Ahmad Dahlan \\ E-mail : gempar.pribadi@gmail.com
}

\begin{abstract}
This study aims to measure the level of satisfaction of students and parents or guardians of students of the quality of service at SMP Muhammadiyah 1 Gombong. The method used in this research is quantitative descriptive. The sample in this study used all members. The sampling technique in this study used a census, totaling 256 respondents (128 grade IX students and 128 parents or guardians of class IX students) in the 2019/2020 school year. The instrument test uses the CFA (Confirmatory Factor Analysis) validity test and Cronbach Alpha reliability. The data analysis technique in this study uses Arithmetic Mean. The results showed that of the total 107 respondent students, students dominantly answered neutral to the human resource variable as much as $28.04 \%$, and the dominant curriculum variable answered very dissatisfied which was $38.32 \%$, and to the dominant infrastructure variable answered very dissatisfied with a number of $35.51 \%$. For parents or guardians of students, from a total of 93 respondents, the human resource variable dominant student guardians answered neutral 55.91\%, the dominant curriculum variable answered neutral a number of $62.37 \%$, and the dominant infrastructure variable said neutral, a number of $55.91 \%$.
\end{abstract}

Keywords: School Service Quality, Student Satisfaction, Student Guardian Satisfaction

\section{ABSTRAK}

Penelitian ini bertujuan untuk mengukur tingkat kepuasan siswa dan orang tua atau wali murid terhadap service quality SMP Muhammadiyah 1 Gombong. Metode yang digunakan dalam penelitian ini adalah deskriptif kuantitatif. Sampel dalam penelitian ini menggunakan seluruh anggota populasi. Teknik sampling pada penelitian ini menggunakan sensus, sebanyak 256 responden (128 siswa kelas IX dan 128 orang tua atau wali murid kelas IX) tahun ajaran 2019/2020. Uji instrumen menggunakan uji validitas CFA (Confirmatory Factor Analysis) dan reliabilitas Cronbach Alpha. Adapun Teknik analisis data dalam penelitian ini menggunakan Aritmatik Mean. Hasil penelitian menunjukkan bahwa dari total responden 107 siswa, secara dominan siswa menjawab netral terhadap variabel sumber daya manusia yaitu sebanyak $28,04 \%$, dan pada variabel kurikulum dominan menjawab sangat tidak puas yaitu sejumlah $38,32 \%$, serta terhadap variabel sarana prasarana dominan menjawab sangat tidak puas yaitu sejumlah $35,51 \%$. Untuk orang tua atau wali murid, dari total responden 93 orang, terhadap variabel sumber daya manusia wali murid dominan menjawab netral 55,91\%, pada variabel kurikulum dominan menjawab netral sejumlah $62,37 \%$, serta pada variabel sarana prasarana dominan menjawab netral yaitu sejumlah 55,91\%.

Kata Kunci: Kualitas Layanan Sekolah, Kepuasan Siswa, Kepuasan Wali Murid

\section{Pendahuluan}

SMP Muhammadiyah 1 Gombong adalah sebuah sekolah swasta berbasis keislaman yang terletak di Kota Gombong, Kabupaten Kebumen. Letaknya yang cukup strategis karena berada di pusat kota dan akses yang mudah dari jalan raya, memunculkan potensi besar untuk mendatangkan calon peserta didik.

Dilengkapi dengan fasilitas yang memadai sebagai bentuk pelayanan kepada peserta didiknya, serta dewan guru dan karyawan yang selalu hangat dalam menyambut anak didiknya, merupakan kelebihan lain dari sekolah ini. Fasilitas yang memadai itu diantaranya adalah tujuh belas ruang kelas, dua laboratorium komputer, laboratorium IPA, musholla, koperasi, mobil sekolah, perpustakaan, ruang kelas ber-AC, multimedia, dll. Belum lagi ditambah label Terakreditasi A (Sekolah Unggul) selama tiga periode berturut - turut sejak 2005 hingga kini, semakin menambah 'amunisi' SMP Muhammadiyah 1 Gombong untuk memenangkan pasar dengan sekolah-sekolah kompetitor.

Belum cukup sampai disitu, beberapa prestasi hebat juga melekat pada sekolah yang sudah berdiri sejak 1948 ini. Diantaranya adalah program rutin pertukaran pelajar yang sudah dilaksanakan sekitar lima tahun ini ke luar negeri seperti ke Singapura, Malaysia, dan Thailand. Belum lagi dengan prestasi para peserta didiknya yang sudah tak terhitung lagi banyaknya, mulai dari yang bersifat akademis hingga non-akademis, baik beregu maupun perorangan, mulai tingkat kecamatan hingga nasional dan internasional.

Meski begitu, kenyataannya jumlah penerimaan peserta didik baru (PPDB) dari tahun ke tahun begitu fluktuatif. Tidak stabil atau berkembang. 
Gambar 1. Jumlah Peserta Didik Baru Lima Tahun Terakhir

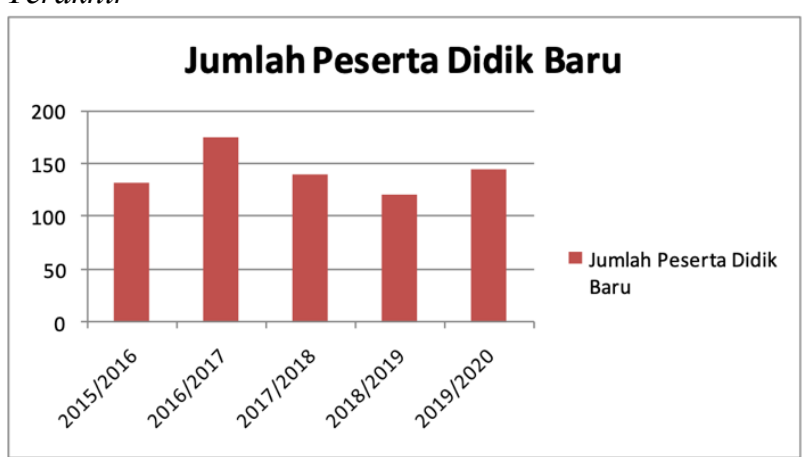

Sumber: Data Tata Usaha SMP Muhammadiyah 1

Gombong (2015 s.d. 2019)

Memang, di sekitar SMP Muhammadiyah 1 Gombong terdapat total enam sekolah kompetitor. Terdiri dari lima sekolah negeri dan satu swasta. Sudah bukan rahasia lagi apabila di daerah Gombong dan sekitarnya SMP dan MTs Negeri menjadi primadona berkat program pemerintah dengan 'Gratis SPP (Surat Persetujuan Pembayaran)'-nya. Hal tersebut benar-benar menghipnotis sebagian besar calon peserta didik baru yang ingin melanjutkan ke jenjang SMP atau MTs. Apabila di sekolah negeri tidak diterima, barulah mereka mencari opsi kedua yaitu sekolah swasta.

Sementara itu, SMP Muhammadiyah 1 Gombong yang notabene adalah sekolah swasta, tidak mungkin latah dan mengikuti program pemerintah Gratis SPP. Sebab untuk gaji guru dan karyawan saja harus mengambil dari mana lagi jika bukan dari SPP? Lalu bagaimana bisa menggaji guru dan karyawan apabila tidak ada pemasukan dari uang SPP siswa?

Menurut Tjiptono (2012) mendefinisikan kualitas pelayanan adalah ukuran seberapa bagus tingkat layanan yang diberikan mampu sesuai dengan ekspektasi pelanggan. Definisi lain kualitas pelayanan menurut Wyckof dalam Lovelock yang dikutip oleh Tjiptono (2012) merupakan tingkat keunggulan (excellence) yang diharapkan dan pengendalian atas keunggulan tersebut untuk memenuhi keinginan pelanggan. Selanjutnya definisi kualitas pelayanan menurut Mauludin (2010) mengemukakan bahwa kualitas pelayanan adalah seberapa jauh perbedaan antara kenyataan dan harapan pelanggan atas langganan yang mereka terima atau peroleh.

Bisa ditarik kesimpulan pengertian dari kualitas pelayanan yaitu segala bentuk penyelenggaraan pelayanan secara maksimal yang diberikan penyedia jasa atau produk dengan segala keunggulan dalam rangka memenuhi kebutuhan pelanggan demi memenuhi harapan pelanggan.

Menurut metode SERVQUAL (Palmer, 2008) yang telah dikutip dari situs https://pustakapusdokinfo, bahwa pada suatu sekolah atau instansi pendidikan banyak berbagai faktor yang mempengaruhi kepuasan siswa terhadap pelayanan yang diberikan sekolah yaitu antara lain sebagai berikut:

1) Sumber Daya Manusia
2) Kurikulum

3) Sarana dan Prasarana

Menurut Supriyanto dan Ernawaty (2010), kepuasan pelanggan terjadi apabila apa yang menjadi kebutuhan, keinginan atau harapan pelanggan dapat terpenuhi. Kepuasan pelanggan adalah perasaan senang atau puas bahwa produk atau jasa yang diterima telah sesuai atau melebihi harapan pelanggan.

Rumusan masalah dalam penelitian ini antara lain menguji apakah siswa kelas IX dan orang tua / wali murid kelas IX puas dengan sumber daya manusia, kurikulum, dan sarana prasarana di SMP Muhammadiyah 1 Gombong.

Tujuan penelitian ini adalah untuk mengukur kepuasan siswa dan orang tua / wali murid terhadap sumber daya manusia, kurikulum, dan sarana prasarana di SMP Muhammadiyah 1 Gombong.

\section{Landasan Teori}

\subsection{Service Quality}

Tjiptono (2012) mendefinisikan kualitas pelayanan adalah ukuran seberapa bagus tingkat layanan yang diberikan mampu sesuai dengan ekspektasi pelanggan. Definisi lain kualitas pelayanan menurut Wyckof dalam Lovelock yang dikutip oleh Tjiptono (2012) merupakan tingkat keunggulan (excellence) yang diharapkan dan pengendalian atas keunggulan tersebut untuk memenuhi keinginan pelanggan. Selanjutnya definisi kualitas pelayanan menurut Mauludin (2010) adalah seberapa jauh perbedaan antara kenyataan dan harapan pelanggan atas langganan yang mereka terima atau peroleh.

Berdasarkan pengertian di atas dapat disimpulkan bahwa kualitas pelayanan adalah suatu kegiatan ekonomi yang outputnya bukan produk konsumsi, bersamaan dengan waktu produksi dan memberikan nilai tambah (seperti kenikmatan, hiburan, santai) bersifat tidak berwujud dan apabila jasa yang diterima oleh pelanggan sesuai dengan yang diharapkan, maka kualitas pelayanan dipersepsikan baik (ideal), dan sebaliknya jika pelayanan yang diterima lebih rendah daripada yang diharapkan konsumen, maka kualitas pelayanan akan dipersepsikan jelek (kurang ideal), sehingga kebutuhan dan keinginan konsumen merasa belum terpenuhi.

Ada dua faktor utama yang mempengaruhi kualitas jasa, yaitu expected service (kualitas jasa yang diharapkan) dan perceived service (kualitas jasa yang diterima atau dirasakan). Apabila jasa yang diterima atau dirasakan sesuai dengan yang diharapkan, maka kualitas jasa dipersepsikan baik dan memuaskan. Sebaliknya jika jasa yang diterima lebih rendah daripada yang diharapkan maka kualitas jasa dipersepsikan sebagai kualitas yang buruk. Kualitas harus dimulai dari kebutuhan pelanggan dan berakhir pada persepsi pelanggan.

Kualitas pelayanan memberikan suatu dorongan kepada pelanggan untuk menjalin ikatan hubungan yang kuat dengan lembaga atau instansi pemberi pelayanan jasa. Ikatan hubungan yang baik ini akan memungkinkan lembaga pelayanan jasa untuk memahami dengan seksama harapan pelanggan serta kebutuhan mereka. 
Menurut Garvin yang dikutip Tjiptono (2012) menyatakan bahwa : "Terdapat lima perspektif mengenai kualitas, salah satunya yaitu bahwa kualitas dilihat tergantung pada orang yang menilainya, sehingga produk yang paling memuaskan preferensi seseorang merupakan produk yang berkualitas paling tinggi".

\subsection{Kepuasan}

Menurut Supriyanto dan Ernawaty (2010) kepuasan pelanggan terjadi apabila apa yang menjadi kebutuhan, keinginan atau harapan pelanggan dapat terpenuhi. Kepuasan pelanggan adalah perasaan senang atau puas bahwa produk atau jasa yang diterima telah sesuai atau melebihi harapan pelanggan.

Menurut Lovelock dan Wirtz (2011) "Kepuasan adalah suatu sikap yang diputuskan berdasarkan pengalaman yang didapatkan. Kepuasan merupakan penilaian mengenai ciri atau keistimewaan produk atau jasa, atau produk itu sendiri, yang menyediakan tingkat kesenangan konsumen berkaitan dengan pemenuhan kebutuhan konsumsi konsumen. Kepuasan konsumen dapat diciptakan melalui kualitas, pelayanan dan nilai. Kunci untuk menghasikan kesetian pelanggan adalah memberikan nilai pelanggan yang tinggi.

Menurut Kotler dan Armstrong (2015), kepuasan pelanggan adalah sejauh mana suatu produk dirasakan kinerja sesuai dengan harapan pembeli. Jika kinerja produk gagal memenuhi harapan pelanggan tidak puas. Jika kinerja sesuai harapan, pelanggan puas. Jika kinerja melebihi harapan, pelanggan sangat puas atau senang.

Menurut metode SERVQUAL (Palmer, 2008) yang telah dikutip dari situs https://pustakapusdokinfo, bahwa pada suatu sekolah atau instansi pendidikan banyak berbagai faktor yang mempengaruhi kepuasan siswa terhadap pelayanan yang diberikan sekolah yaitu antara lain sebagai berikut:

1) Sumber Daya Manusia

Hal-hal yang berkaitan dengan sumber daya manusia meliputi:

a. Sistem perekrutan guru.

b. Kecukupan jumlah guru.

c. Kualifikasi guru dalam hal ini terkait pendidikan.

d. Program pembinaan, pengembangan, dan jaminan kesejahteraan.

e. Tenaga Kependidikan.

f. Kecukupan dan kualifikasi petugas perpustakaan.

g. Kode etik atau pedoman disiplin kerja guru dan tenaga kependidikan, yang lengkap dan jelas serta implementasinya.

2) Kurikulum

Berdasarkan Undang-undang Republik Indonesia nomor 20 tahun 2003 tentang Sistem Pendidikan Nasional bahwa kurikulum adalah seperangkat rencana dan mengenai tujuan, isi, dan bahan pelajaran serta cara yang digunakan sebagai pedoman penyelenggaran pembelajaran untuk mencapai tujuan pendidikan tertentu. Kurikulum merupakan dimensi yang terkait dengan manajemen dan kapsitas sekolah untuk merencanakan dan memberikan layanan yang memenuhi kebutuhan siswa. Program yang mendorong atau memfasilitasi Program Studi (sekolah) untuk perbaikan isi kurikulum secara berkesinambungan, meliputi:

a. Pendekatan pembelajaran.

b. Design pembelajaran.

c. Relevansi isi.

d. Media pembelajaran.

e. Evaluasi proses dan hasil pembelajaran.

f. Umpan balik dari stakeholders.

3) Sarana dan Prasarana

Berdasarkan Undang-Undang Republik Indonesia nomer 20 Tahun 2003 tentang Sistem Pendidikan Nasional menjelasakan bahwa setiap satuan pendidikan formal dan nonformal menyediakan sarana dan prasarana yang memenuhi keperluan pendidikan sesuai dengan pertumbuhan dan perkembangan fisik, kecerdasan intelektual, sosial, emosional, dan kejiwaan peserta didik.

a. Sarana meliputi peralatan dan perabotan kantor, peralatan laboratorium serta fasilitas komputer.

b. Prasarana meliputi lahan, ruang guru, serta ruang diskusi.

Dari penjelasan para ahli tentang dimensi kualitas pelayanan jasa dan kepuasan siswa di atas, maka dapat disimpulkan beberapa dimensi yang sesuai agar pelayanan jasa pendidikan dapat memberikan kepuasan kepada para pelanggan jasa (siswa dan wali murid). Adapun dimensi tersebut yaitu sumber daya manusia, kurikulum, dan sarana prasarana. Dalam penelitian ini ketiga dimensi tersebut digunakan sebagai indikator pengukuran kualitas pelayanan jasa pendidikan terhadap kepuasan siswa dan wali murid.

\subsection{Metode Penelitian}

Rancangan penelitian ini menggunakan jenis penelitian kuantitatif. Menurut Sugiyono (2012), pendekatan kuantitatif dapat diartikan sebagai metode penelitian yang berdasarkan pada populasi atau sampel tertentu. Instrumen penelitian yang digunakan oleh penulis yaitu kuesioner.

Jumlah responden yang mengisi kuesioner dalam penelitian ini seharusnya masing-masing berjumlah 128 orang untuk siswa, dan 128 orang untuk orang tua / wali murid kelas IX. Namun pada saat dilaksanakan pengisian kuesioner ada beberapa siswa yang tidak berangkat sekolah karena sakit dan izin, serta ada yang sedang mendapat tugas dari sekolah, sehingga untuk jumlah responden siswa berjumlah 107 orang.

Adapun responden orang tua / wali murid kelas IX juga ada sebagian yang berhalangan hadir saat pengisian kuesioner, sehingga jumlah responden orang tua / wali murid berjumlah 93 orang. Maka secara jelas jumlah populasi dalam penelitian ini adalah: 
Tabel 1. Jumlah Responden

\begin{tabular}{|c|c|c|c|}
\hline NO & RESPONDEN & $\begin{array}{c}\text { JUMLAH } \\
\text { SEHARUSNYA }\end{array}$ & $\begin{array}{c}\text { JUMLAH YANG MENGISI } \\
\text { KUESIONER }\end{array}$ \\
\hline 1. & Siswa Kelas IX & 128 orang & 107 orang \\
\hline 2. & $\begin{array}{l}\text { Orang tua / Wali murid } \\
\text { Kelas IX }\end{array}$ & 128 orang & 93 orang \\
\hline & Jumlah & 256 orang & 200 orang \\
\hline
\end{tabular}

Sumber: Data Tata Usaha SMP Muhammadiyah 1 Gombong (2019)

Penelitian ini menggunakan skala ordinal, yaitu skala pengukuran yang sudah menyatakan peringkat antar tingkatan. Jarak atau interval antar tingkatan juga tidak harus sama. Di dalam skala ordinal, objek atau kategorinya disusun berdasarkan urutan tingkatannya, dari tingkat terendah ke tingkat tertinggi atau sebaliknya.

Di dalam sebuah penelitian, kategori tersebut bisa disimbolkan dengan angka, misal angka 5 untuk sangat setuju, angka 4 untuk setuju, angka 3 untuk biasa saja, angka 2 untuk tidak setuju, dan angka 1 untuk sangat tidak setuju.

Dalam hal ini skala ordinal yang digunakan adalah:

Tabel 2. Skala Ordinal yang Digunakan

\begin{tabular}{|l|c|c|c|c|c|c|c|c|c|c|}
\hline & \multicolumn{5}{|c|}{ Harapan } & \multicolumn{5}{|c|}{ Kinerja } \\
\hline Kategori & SP & P & N & TP & STP & SS & S & N & TS & STS \\
\hline Nilai & 5 & 4 & 3 & 2 & 1 & 5 & 4 & 3 & 2 & 1 \\
\hline
\end{tabular}

Sumber: www.ekspektasia.com (2017)

Keterangan:

$\begin{array}{ll}\text { SP } & \text { : sangat penting } \\ \text { SS } & \text { : sangat setuju } \\ \text { P } & \text { : penting } \\ \text { S } & \text { : setuju } \\ \text { N } & \text { : netral } \\ \text { N } & \text { : netral } \\ \text { TP } & \text { : tidak penting } \\ \text { TS } & \text { : tidak setuju } \\ \text { STP } & \text { : sangat tidak penting } \\ \text { STS } & \text { : sangat tidak setuju }\end{array}$

\section{Pembahasan}

\subsection{Hasil Analisis}

1. Kepuasan Siswa dan Wali Murid

Keterangan :

STP $=$ Sangat Tidak Puas $($ Nilai $\leq-3)$

$\mathrm{TP}=$ Tidak Puas $(-3<$ Nilai $<0)$

$\mathrm{N} \quad=$ Netral $($ Nilai $=0)$

$\mathrm{P} \quad=$ Puas $(0<$ Nilai $<2)$

$\mathrm{SP}=$ Sangat Puas (Nilai $\geq 3$ )

Tabel 3. Kepuasan Siswa

\begin{tabular}{|l|c|c|c|c|c|c|}
\hline \multirow{2}{*}{ Variabel } & STP & TP & N & P & SP & $\begin{array}{c}\text { Jumlah } \\
\text { Responden }\end{array}$ \\
\cline { 2 - 6 } & \multicolumn{5}{|c|}{ DALAM PERSEN (\%) } & 107 \\
\hline $\begin{array}{l}\text { Sumber Daya } \\
\text { Manusia }\left(\mathrm{X}_{1}\right)\end{array}$ & 23,36 & 22,43 & 28,04 & 21,50 & 4,67 & 107 \\
\hline Kurikulum $\left(\mathrm{X}_{2}\right)$ & 38,32 & 18,69 & 21,50 & 18,69 & 2,80 & 107 \\
\hline $\begin{array}{l}\text { Sarana Prasarana } \\
\left(\mathrm{X}_{3}\right)\end{array}$ & 35,51 & 16,82 & 31,78 & 11,21 & 4,67 & 107 \\
\hline
\end{tabular}

Berdasarkan tabel 3 tentang Kepuasan Siswa, pada variabel Sumber Daya Manusia Siswa Kelas IX dominan menjawab Netral (N) yaitu sebesar 28,04\%. Untuk variabel Kurikulum Siswa Kelas IX dominan menjawab Sangat Tidak Puas (STP) yaitu sebesar 38,32\%. Adapun untuk variabel Sarana Prasarana Siswa Kelas IX juga dominan menjawab Sangat Tidak Puas (STP) yaitu sebesar $35,51 \%$.

Tabel 4. Kepuasan Wali Murid

\begin{tabular}{|c|c|c|c|c|c|c|}
\hline \multirow{2}{*}{ Variabel } & STP & TP & $\mathbf{N}$ & $\mathbf{P}$ & SP & \multirow{2}{*}{$\begin{array}{c}\text { Jumlah } \\
\text { Responden }\end{array}$} \\
\hline & \multicolumn{5}{|c|}{ DALAM PERSEN (\%) } & \\
\hline $\begin{array}{l}\text { Sumber Daya } \\
\text { Manusia }\left(X_{1}\right)\end{array}$ & 28,04 & 21,50 & 55,91 & 9,68 & 0,00 & 93 \\
\hline Kurikulum $\left(\mathrm{X}_{2}\right)$ & 11,83 & 12,90 & 62,37 & 10,75 & 2,15 & 93 \\
\hline $\begin{array}{l}\text { Sarana Prasarana } \\
\left(\mathrm{X}_{3}\right)\end{array}$ & 16,13 & 16,13 & 55,91 & 8,60 & 3,23 & 93 \\
\hline
\end{tabular}

Berdasarkan tabel 4 tentang Kepuasan Wali Murid, pada variabel Sumber Daya Manusia Wali Murid Kelas IX dominan menjawab Netral (N) yaitu sebesar 55,91\%. Untuk variabel Kurikulum Wali Murid Kelas IX dominan menjawab Netral (N) yaitu sebesar 62,37\%. Adapun untuk variabel Sarana Prasarana Wali Murid Kelas IX juga dominan menjawab Netral $(\mathrm{N})$ sebesar 55,91\%.

2. Kepuasan Siswa dan Wali Murid Berdasarkan Item Setiap Variabel

Untuk mengetahui item/aspek mana yang memiliki pengaruh paling besar dalam kepuasan atau ketidakpuasan siswa dan wali murid, perlu dilaporkan pula selisih nilai rata-rata per item (pertanyaan). Berikut penulis sajikan laporan rincinya.

Tabel 5. Hasil Kepuasan Siswa Terhadap Sumber Daya Manusia

\begin{tabular}{|l|c|c|c|}
\hline \multicolumn{1}{|c|}{ Item } & Nilai Harapan & Nilai Kinerja & Selisih \\
\hline $\begin{array}{l}\text { Tenaga Kependidikan } \\
\text { yang profesional }\end{array}$ & 4,32 & 4,13 & $-0,19$ \\
\hline $\begin{array}{l}\text { Jumlah petugas } \\
\text { perpustakaan memadai }\end{array}$ & 3,80 & 3,73 & $-0,07$ \\
\hline $\begin{array}{l}\text { Kualitas petugas } \\
\text { perpustakaan memadai }\end{array}$ & 4,04 & 3,75 & $-0,30$ \\
\hline $\begin{array}{l}\text { Pendidik (Guru) melayani } \\
\text { dengan baik sesuai kode } \\
\text { etik }\end{array}$ & 4,38 & 4,20 & $-0,18$ \\
\hline $\begin{array}{l}\text { Tenaga kependidikan } \\
\text { (Staff TU) melayani } \\
\text { dengan baik sesuai kode } \\
\text { etik }\end{array}$ & 4,36 & 4,25 & $-0,11$ \\
\hline
\end{tabular}


Tabel 6. Hasil Kepuasan Siswa Terhadap Kurikulum

\begin{tabular}{|l|c|c|c|}
\hline \multicolumn{1}{|c|}{ Item } & Nilai Harapan & Nilai Kinerja & Selisih \\
\hline $\begin{array}{l}\text { Guru melakukan pendekatan } \\
\text { pembelajaran yang menarik }\end{array}$ & 4,40 & 4,01 & $-0,39$ \\
\hline Desain pembelajaran menarik & 4,31 & 3,78 & $-0,53$ \\
\hline $\begin{array}{l}\text { Kegiatan Belajar Mengajar } \\
\text { sesuai dengan kebutuhan siswa }\end{array}$ & 4,29 & 4,02 & $-0,27$ \\
\hline $\begin{array}{l}\text { Media pembelajaran yang } \\
\text { memadai }\end{array}$ & 4,30 & 3,99 & $-0,31$ \\
\hline $\begin{array}{l}\text { Evaluasi hasil pembelajaran } \\
\text { (rapot) disaijkan secara } \\
\text { lengkap }\end{array}$ & 4,49 & 4,10 & $-0,39$ \\
\hline $\begin{array}{l}\text { Sekolah memberi kesempatan } \\
\text { kepada wali murid untuk } \\
\text { memberi masukan / kritik } \\
\text { membangun kepada sekolah }\end{array}$ & 4,04 & 3,70 & $-0,33$ \\
\hline
\end{tabular}

Tabel 7. Hasil Kepuasan Siswa Terhadap Sarana Prasarana

\begin{tabular}{|l|c|c|c|}
\hline \multicolumn{1}{|c|}{ Item } & Nilai Harapan & Nilai Kinerja & Selisih \\
\hline $\begin{array}{l}\text { Sarana (peralatan, } \\
\text { perabotan, dll) kelas } \\
\text { memadai }\end{array}$ & 4,39 & 3,86 & $-0,53$ \\
\hline $\begin{array}{l}\text { Sarana (peralatan, } \\
\text { perabotan, dll) sekolah } \\
\text { memadai }\end{array}$ & 4,46 & 4,09 & $-0,37$ \\
\hline $\begin{array}{l}\text { Laboratorium IPA } \\
\text { peralatannya memadai }\end{array}$ & 4,40 & 4,19 & $-0,21$ \\
\hline $\begin{array}{l}\text { Laboratorium Komputer } \\
\text { peralatannya memadai }\end{array}$ & 4,5 & 4,17 & $-0,33$ \\
\hline $\begin{array}{l}\text { Lahan sekolah memadai } \\
\text { untuk kegiatan sekolah }\end{array}$ & 4,34 & 3,80 & $-0,55$ \\
\hline
\end{tabular}

Tabel 8. Hasil Kepuasan Wali Murid terhadap Sumber Daya Manusia

\begin{tabular}{|l|c|c|c|}
\hline \multicolumn{1}{|c|}{ Item } & Nilai Harapan & Nilai Kinerja & Selisih \\
\hline $\begin{array}{l}\text { Kualifikasi guru sudah } \\
\text { sesuai dengan mata } \\
\text { pelaiaran yang diampu }\end{array}$ & 4,60 & 4,45 & $-0,15$ \\
\hline $\begin{array}{l}\text { Jumlah petugas } \\
\text { perpustakaan memadai }\end{array}$ & 4,46 & 4,15 & $-0,31$ \\
\hline $\begin{array}{l}\text { Pendidik (Guru) } \\
\text { melayani dengan baik } \\
\text { sesuai kode etik }\end{array}$ & 4,82 & 4,70 & $-0,12$ \\
\hline $\begin{array}{l}\text { Tenaga kependidikan } \\
\text { (Staff TU) melayani } \\
\text { dengan baik sesuai kode } \\
\text { etik }\end{array}$ & 4,78 & 4,65 & $-0,14$ \\
\hline
\end{tabular}

Tabel 9. Hasil Kepuasan Wali Murid Terhadap Kurikulum

\begin{tabular}{|c|c|c|c|}
\hline Item & $\begin{array}{c}\text { Nilai } \\
\text { Harapan }\end{array}$ & Nilai Kinerja & Selisih \\
\hline $\begin{array}{l}\text { Guru melakukan } \\
\text { pendekatan } \\
\text { pembelajaran yang } \\
\text { menarik }\end{array}$ & 4,86 & 4,69 & $-0,17$ \\
\hline $\begin{array}{l}\text { Desain pembelajaran } \\
\text { menarik }\end{array}$ & 4,56 & 4,44 & $-0,12$ \\
\hline $\begin{array}{l}\text { Media pembelajaran } \\
\text { yang memadai }\end{array}$ & 4,77 & 4,65 & $-0,13$ \\
\hline $\begin{array}{l}\text { Sekolah memberi } \\
\text { kesempatan kepada } \\
\text { wali murid untuk } \\
\text { memberi masukan / } \\
\text { kritik membangun } \\
\text { kepada sekolah }\end{array}$ & 4,56 & 4,37 & $-0,19$ \\
\hline
\end{tabular}

Tabel 10. Hasil Kepuasan Wali Murid Terhadap Sarana Prasarana

\begin{tabular}{|l|c|c|c|}
\hline \multicolumn{1}{|c|}{ Item } & Nilai Harapan & Nilai Kinerja & Selisih \\
\hline $\begin{array}{l}\text { Sarana (peralatan, } \\
\text { perabotan, dll) kelas } \\
\text { memadai }\end{array}$ & 4,54 & 4,31 & $-0,23$ \\
\hline $\begin{array}{l}\text { Sarana (peralatan, } \\
\text { perabotan, dll) } \\
\text { sekolah memadai }\end{array}$ & 4,51 & 4,37 & $-0,14$ \\
\hline $\begin{array}{l}\text { Laboratorium IPA } \\
\text { peralatannya } \\
\text { memadai }\end{array}$ & 4,76 & 4,51 & $-0,26$ \\
\hline $\begin{array}{l}\text { Laboratorium } \\
\text { Komputer } \\
\text { peralatannya } \\
\text { memadai }\end{array}$ & 4,73 & 4,53 & $-0,20$ \\
\hline $\begin{array}{l}\text { Lahan sekolah } \\
\text { memadai untuk } \\
\text { kegiatan sekolah }\end{array}$ & 4,58 & 4,37 & $-0,22$ \\
\hline
\end{tabular}

\subsection{Diskusi}

Tjiptono dan Chandra dalam bukunya yang berjudul 'Service, Quality \& Satisfaction' (2016) mengatakan bahwa kualitas pelayanan berkontribusi signifikan bagi penciptaan diferensiasi, positioning, dan strategi bersaing bagi setiap organisasi, baik organisasi manufaktur maupun industri penyedia jasa, seperti industri pendidikan. Kualitas pelayanan pada akhirnya juga dapat menciptakan hubungan yang harmonis antara penyedia barang dan jasa dengan pelanggan, memberikan dasar yang baik bagi terciptanya loyalitas pelanggan dan membentuk suatu rekomendasi dari mulut ke mulut (word of mouth) yang menguntungkan bagi penyedia jasa tersebut.

Berdasarkan penelitian yang sudah dilakukan, maka dapat kita simpulkan bahwa baik siswa kelas IX maupun wali murid kelas IX belum merasa puas dengan kualitas layanan dari SMP Muhammadiyah 1 Gombong. Mulai dari sumber daya manusia, kurikulum, hingga sarana prasarana tidak ada satupun diantara variabel tersebut yang membuat siswa dan wali murid merasa puas.

a. Variabel Sumber Daya Manusia

Variabel sumber daya manusia yang paling rendah tingkat kepuasannya adalah mengenai jumlah dan kualitas layanan karyawan perpustakaan. Dengan jumlah staff yang hanya dua orang, sementara yang salah satu juga merangkap sebagai kurir sekolah, menjadi salah satu penyebab kurang maksimalnya pelayanan perpustakaan. Adapun hal lain dalam variabel sumber daya manusia yang menjadi penyebab kurang puasnya siswa dan wali murid adalah adanya beberapa guru yang mengajar tidak sesuai bidang pendidikannya.

b. Variabel Kurikulum

Variabel kurikulum menjadi variabel yang paling rendah tingkat kepuasannya diantara dua variabel lainnya. Poin terendah dalam variabel kurikulum adalah tentang desain pembelajaran yang kurang menarik. Ini menjadi evaluasi yang serius untuk pihak sekolah, karena bagaimanapun kurikulum termasuk salah satu 
faktor penting dalam keberlangsungan sebuah sekolah.

c. Variabel Sarana Prasarana

Variabel sarana prasarana yang paling rendah tingkat kepuasannya adalah tentang kurangnya lahan sekolah. Bisa dimaklumi, dengan sempitnya lahan sekolah, ruang gerak siswa juga menjadi terbatas. Bahkan untuk kegiatankegiatan sekolah pun sering terganggu, terlebih jika banyak kendaraan baik mobil ataupun motor yang parkir di halaman sekolah

Tidak puasnya siswa dan wali murid terhadap tiga variabel di atas sebenarnya cukup mengejutkan, mengingat begitu banyak potensi yang dimiliki oleh SMP Muhammadiyah 1 Gombong. Namun penyebab ketidakpuasan siswa dan wali murid bisa bermacammacam. Bisa berasal dari faktor internal sekolah, namun juga bisa karena faktor eksternal. Faktor internal sekolah contohnya adalah kurang maksimalnya sekolah dalam menjaga kualitas layanan. Mulai dari menjaga dan meningkatkan kualitas guru karyawan, menyusun program kurikulum yang menarik, hingga pengadaan sarana prasarana. Selain itu faktor internal bisa juga karena harapan siswa dan wali murid yang terlalu tinggi.

Harapan yang tinggi dari wali murid sebenarnya bisa dimaklumi, karena mereka harus mengeluarkan uang untuk membayar SPP setiap bulan dan uang pengembangan setiap tahunnya. Hal tersebut membuat mereka 'berhak' untuk mengharapkan standar yang tinggi untuk kualitas layanan sekolah. Itu semua karena SMP Muhammadiyah 1 Gombong adalah sekolah swasta yang mau tidak mau harus mengambil dana dari wali murid sebagai salah satu sumber dana operasional sekolah.

Adapun faktor eksternal bisa berasal dari isu-isu yang beredar di masyarakat, kurangnya komunikasi pihak sekolah dengan pihak luar, kurangnya tepatnya model promosi sekolah, hingga ketatnya persaingan dengan kompetitor (sekolah-sekolah) lain.

Seperti teori yang diungkapkan oleh Tjiptono dan Chandra (2016) tadi, bahwa jika sekolah bisa memberikan pelayanan yang maksimal dan memuaskan pelanggan (dalam hal ini siswa dan wali murid), maka dengan sendirinya akan tersebar kabar bahwa SMP Muhammadiyah 1 Gombong adalah sekolah yang berkualitas. Hal itu tentu dengan sendirinya akan membentuk diferensiasi, positioning, dan strategi bersaing tidak hanya bagi SMP Muhammadiyah 1 Gombong saja, melainkan juga untuk nama Muhammadiyah secara umum akan terkena imbas baiknya.

\section{Kesimpulan} berikut :

Kesimpulan dari penelitian ini adalah sebagai

1. Dari total responden 107 orang, siswa dominan menjawab netral (sejumlah 30 siswa atau $28,04 \%$ ) terhadap variabel sumber daya manusia.
2. Dari total responden 107 orang, siswa dominan menjawab sangat tidak puas (sejumlah 41 siswa atau 38,32\%) terhadap variabel kurikulum.

3. Dari total responden 107 orang, siswa dominan menjawab Sangat Tidak Puas (sejumlah 38 siswa atau 35,51\%) terhadap variabel sarana prasarana.

4. Dari total responden 93 orang, wali murid dominan menjawab netral (sejumlah 52 orang atau 55,91\%) terhadap variabel sumber daya manusia.

5. Dari total responden 93 orang, siswa dominan menjawab netral (sejumlah 41 orang atau $62,37 \%$ ) terhadap variabel kurikulum.

6. Dari total responden 93 orang, siswa dominan menjawab netral (sejumlah 52 orang atau $55,91 \%$ ) terhadap variabel sarana prasarana.

Melihat hasil penelitian dimana tidak ada satupun variabel yang hasilnya memuaskan, itu artinya perlu diadakan evaluasi mendalam dan menyeluruh terhadap tiga variabel di atas. Terutama pada poin-poin yang memiliki angka minus terbesar, seperti tentang tenaga perpustakaan, model pembelajaran, dan lahan sekolah.

Beberapa solusi supaya sekolah bisa meningkatkan kualitas pelayanan diantaranya :

1. Pengecekan secara menyeluruh dan detail terhadap variabel-variabel di atas yang ada di SMP Muhammadiyah 1 Gombong. Supervisi tidak hanya untuk guru, melainkan untuk karyawan juga, adanya rancangan pembelajaran yang lebih menarik, hingga meningkatkan kualitas sarana prasarana.

2. Menjalin komunikasi yang baik dengan wali murid dan stakeholder. Bukan tidak mungkin akan ada bantuan dari pihak-pihak luar yang dapat membantu program-program dan meningkatkan kualitas layanan sekolah.

3. Membuat program pencitraan sekolah yang gencar dan tepat

4. Studi banding ke sekolah lain yang karakteristiknya mirip dengan SMP Muhammadiyah 1 Gombong namun sudah memiliki kualitas layanan yang lebih baik, sebagai bahan acuan dan pembelajaran, serta meningkatkan kualitas sumber daya manusia.

5. SMP Muhammadiyah 1 Gombong harus segera memiliki sumber pendapatan lain selain SPP dan Uang Pengembangan dari wali murid. Supaya program-program serta layanan sekolah tidak tergantung pada lancar tidaknya wali murid membayar uang sekolah.

6. Mulai memikirkan rancangan kurikulum yang menarik dan beda dari sekolah lain, sehingga akan ada keunikan tersendiri yang bisa menjadi branding sekolah di mata masyarakat.

\section{Daftar Pustaka}

Tjiptono, Fandi. 2015. Strategi Pemasaran Edisi IV. Yogyakarta : Penerbit Andi. 
Shaleh, Abdul Rahman. 2014. Psikologi Suatu Pengantar Dalam Perspektif Islam. Jakarta : Prenada Media.

Tjiptono, Fandi., dan Chandra, Gregorius. 2016. Service, Quality \& Satisfaction. Yogyakarta : Penerbit Andi.

Fasani, Rizkan Faif. 2016. Pengaruh Kualitas Layanan Pendidikan Terhadap Kepuasan Siswa di SMA MTA Surakarta Tahun 2016. Surakarta : UNS.

Tjiptono, Fandi., dan Chandra, Gregorius. 2012. Pemasaran Strategik. Yogyakarta : Penerbit Andi.

Mauludin, Hanif. 2010. Marketing Research: Panduan Bagi Manajer, Pimpinan Perusahaan Organisasi. Jakarta: Elex Media Komputindo.

Supriyanto, S. dan Ernawati, 2010. Pemasaran Industri Jasa Kesehatan. Yogyakarta : Penerbit CV Andi Offset

Undang-undang Republik Indonesia Nomor 20 Tahun 2003 tentang Standar Nasional Pendidikan.

Sopiatin, Popi. (2010). Manajemen Belajar Berbasis Kepuasan Siswa. Cilegon: Ghalia Indonesia.

Rafisqy, Zhafran Ghani Al. (2017, 11 Oktober). Skala Pengukuran dalam Ilmu Statistik Lengkap Contoh. Dikutip $13 \quad$ September 2019 dari https://ekspektasia.com/skala-pengukuran/

Sugiyono. 2012. Metode Penelitian Bisnis. Bandung : Alfabeta.

A. Zeithaml, V. Parasuraman, A. and L. Berry L. 1985. "Problems and Strategies in Services Marketing". Jurnal of Marketing Vol. 49. (Spring).

Lovelock, C, dan Wirtz, John. 2011. Pemasaran Jasa Perspektif edisi 7. Jakarta : Erlangga

Armstrong, Gary dan Philip Kotler. 2015. Dasar-dasar Pemasaran. Jilid 1. Jakarta : Prenhalindo.

Bitner, M. J. dan Zeithaml, V. A.. 2003. Service Marketing (3rd ed.). New Delhi : Tata McGraw Hill

Sugiyono. 2010. Metode Penelitian Pendidikan Pendekatan Kuantitatif, Kualitatif, dan $R \& D$. Bandung: Alfabeta.

Rangkuti, Freddy. (2011). Riset Pemasaran. Jakarta, PT. Gramedia Pustaka.

Ghozali, Imam. 2004. Aplikasi Analisis Multivariate dengan Program SPSS. Semarang : Badan Penerbitan Universitas Diponegoro.

Kuntjojo. 2009. Metode Penelitian. Kediri: Universitas Nusantara PGRI.

Sudjana, Nana. 2004. Dasar-dasar Proses Belajar Mengajar. Bandung : Sinar

Sugiyono. 2005. Metode Penelitian Bisnis. Bandung: Alfabeta.

Gasela, Ega. 2018. Pengaruh Dimensi Kualitas Pelayanan Jasa Terhadap Kepuasan Peserta Didik Pada Lembaga Bimbingan Belajar Bahana Ilmu Kota Bandar Lampung [skripsi]. Bandar Lampung. Universitas Lampung.

Marlius, Doni. 2017. Pengaruh Dimensi Kualitas Pelayanan Website Akademik Terhadap Kepuasan Mahasiswa pada STIE "KBP". Jurnal Iptek Terapan. 12 (i2). 116-128.

Ningsih, Dyah Ayu, dkk. 2018. Hubungan Persepsi Tentang Kualitas dan Pelayanan Pendidikan dengan Kepuasan Orang Tua Siswa Sekolah Menengah
Kejuruan Negeri. Jurnal Adminitrasi dan Manajemen Pendidikan. 1 (2). 245-254.

Putra, I Komang Mahayana. dkk. 2015. Pengaruh Kualitas Pelayanan Terhadap Kepuasan Mahasiswa, Citra, dan Positive Word Of Mouth Politeknik Negeri Bali. Jurnal Bisnis dan Kewirausahaan. 11 (1). 90-102.

Rahmidini, Annisa. dkk. 2015. Pengaruh Kualitas Pendidikan Terhadap Kepuasan Mahasiswa Lulusan Prodi DIII Kebidanan di STIKES Respati Tasikmalaya. CR Journal. 1 (1). 31-46.

Yuniarti, Yenny. 2014. Pengaruh Kualitas Pelayanan terhadap Kepuasan Mahasiswa Program Ekstensi Fakultas Ekonomi Universitas Jambi. Trikonomika. 13 (1). 49-61. 